\title{
Factors That Lead to Money Laundering in the Real Estate Sector Based on the Financial Action Task Force Standards
}

\author{
Dennis Chisenga ${ }^{1}$, Jackson Phiri² \\ ${ }^{1}$ Graduate School of Business, The University of Zambia, Lusaka, Zambia \\ ${ }^{2}$ Department of Computer Science, School of Natural, The University of Zambia, Lusaka, Zambia \\ Email: chisengadennis@yahoo.com, Jackson.phiri@cs.unza.zm
}

How to cite this paper: Chisenga, D., \& Phiri, J. (2021). Factors That Lead to Money Laundering in the Real Estate Sector Based on the Financial Action Task Force Standards. Open Journal of Business and Management, 9, 385-396.

https://doi.org/10.4236/ojbm.2021.91020

Received: December 8, 2020

Accepted: January 26, 2021

Published: January 29, 2021

Copyright $\odot 2021$ by author(s) and Scientific Research Publishing Inc. This work is licensed under the Creative Commons Attribution International License (CC BY 4.0).

http://creativecommons.org/licenses/by/4.0/

\begin{abstract}
The study aim was to identify factors that lead to money laundering in the real estate sector based on the Financial Action Task Force Standards. A descriptive cross-sectional study was conducted and both quantitative and qualitative data were collected to better understand the money laundering in the real estate sector in a bid to address the factors that lead to money laundering. Simple random sampling and purposive sampling were used in this research. SPSS was used to analyse the quantitative data and the qualitative data was transcribed and analyzed based on the recurring themes. The study results are that effective AML in the real estate sector relies on the AML training and effective Internal Controls by real estate agents. The results presented a $p$-value of 0.008 which was less than 0.05 . This indicated that the model was statistically significant in explaining the impact of the independent variables on the effectiveness of AML in the real estate sector in Zambia.
\end{abstract}

\section{Keywords}

Money Laundering (ML), Financial Action Task Force (FATF) Standards, Real Estate Agents

\section{Introduction}

The Financial Action Task Force (FATF) in its recommendations stipulates that countries should require Designated Non-Financial Businesses and Professions (DNFBPs) to identify, assess and take effective action to mitigate their money laundering (ML) risks. The FATF is an independent inter-governmental body that develops and promotes policies to protect the global financial system against 
money laundering, terrorist financing and the financing of proliferation of weapons of mass destruction. The FATF Recommendations are recognised as the global antimony laundering (AML) and counter-terrorist financing (CFT) standards (FATF, 2012). Zambia like any other country that has a number of bilateral agreements and a state party to a number of conventions and protocols is required to implement this requirement.

According to the Prohibition and Prevention of Money Laundering Act (PPMLA) No. 14 of 2001 (As Amended by PPML Act No. 44 of 2010), in Zambia Money laundering is defined as, "where a reasonable inference may be drawn, having regard to the objective factual circumstances, any activity by a person:

(a) Who knows or has reason to believe that the property is the proceeds of a crime; or

(b) Without reasonable excuse, fails to take reasonable steps to ascertain whether or not the property is proceeds of a crime.

Where the person:

1) Engages, directly or indirectly, in a transaction that involves proceeds of crime.

2) Acquires, receives, possess, disguises, transfers, converts, exchanges, carries, disposes, uses, removes from or brings into Zambia proceeds of a crime; or

3) Conceals, disguises or impedes the establishment of the true nature, origin, location, movement, disposition, title of, rights with respect to, or ownership of, proceeds of crime".

According to the Zambia National Money Laundering and Terrorist Financing (ML/TF) Risk Assessment (NRA) Report, the DNFBPs as per FATF standards that operate in Zambia include real estate agents, legal practitioners, accountants and auditors, motor vehicle dealers, casinos, precious stones and metal dealers.

Real estate agents are regulated by the Zambia Institute of Estate Agents (ZIEA), which is established under the Estate Agents Act, No. 21 of 2000. The role of ZIEA under section 5 of the Estates Agents Act includes:

1) To promote and regulate the practice and business of estate agents;

2) To promote and maintain best standards and practices in the business of estate agents;

3) To register members of the institute and persons qualified to be registered as estate agents and to maintain a register for both;

4) To provide continuing education for its members; and

5) To regulate the professional conduct and discipline of estate agent.

\subsection{Empirical Review of Literature}

The problem of money laundering has been faced worldwide and many countries have tried to tackle it using various Anti-Money Laundering frameworks. According to a European Parliamentary Research Service (EPRS) paper issued in February 2019 by Remeur (2019), the recommendations increase transparency 
and enable countries to take successful action against the illicit use of their financial systems. Cécile Remeur explains that in the European Union, the first anti-money-laundering framework dates back to the 1990s. It has been revised constantly in order to mitigate risks relating to money laundering and terrorist financing. Cécile Remeur further assumes that the use of real estate for laundering money is concentrated in a number of geographical areas.

DNFBPs are required to run customer due diligence checks based on risk assessment and recordkeeping requirements. This includes real estate agents involved in transactions for their clients concerning the buying and selling of real estate and also lawyers when preparing or carrying out such transactions for their clients. To this end, guidance can help gatekeepers to identify risks and implement obligations. Among the gatekeepers, the financial sector also has a role to play when it is involved in the transaction. This role is important but should not be over-relied upon, as not all transactions pass through a financial sector intermediary, especially in the case of cash transactions. The legal professions have a particular role to play, as they sometimes provide advice on structures and contracts relating to transactions and can be involved in conveyancing. In order to detect and if need be reporting suspicious transactions, there is a need to ascertain the true identity of each customer by running a customer due diligence (CDD)/know your customer process (KYC) (i.e. identifying and verifying the identity of clients, monitoring transactions and reporting suspicious transactions). This spans from the simple identification and verification of the identity of clients (in the case of real estate transactions, the vendor, the purchaser and any other parties involved) to the more complex identification of the beneficial owner. Identifying the beneficial owner, who may be shielded either behind a third party acting as legal owner or behind a corporate vehicle, such as a company (a shell company for instance), a trust or a similar vehicle. Suspicious transaction reporting (STR) must take place when there is suspicion or reasonable grounds to suspect that funds are the proceeds of a criminal activity.

World Scenario: The models used for Anti-Money Laundering by various countries and by various institutions vary according to country but are aligned to international standards. It may be worthwhile to have a look at the problem of money laundering in the real estate sector worldwide. According to an article published by Accuity et al. (2019), entitled "Money laundering and real estate, why the real estate sector should prepare for regulation", Money Laundering is a world-wide problem. Accuity et al. (2019) further explains the levels of money laundering in selected countries as shown below.

Canada: More than 650 organised criminal groups are involved in mortgage fraud to launder funds. Almost half of the 100 most valuable residential properties in Greater Vancouver are held through a structure that hides their beneficial owner.

United Kingdom: Individuals or companies with a high money laundering risk own more than $£ 4.2$ billion of property in London. According to govern- 
ment figures, foreign companies own about 100,000 properties in England and Wales and more than 44,000 in London.

United States: About $\$ 8$ billion are spent each year on $5 \mathrm{~m}+$ homes in New York City, just over half of them to shell companies. 59\% of property purchases by international clients across the US are made in cash. $62 \%$ of property purchases of more than $\$ 2$ million by international clients in New York are made in cash.

Australia: The amount of foreign money invested in Australian real estate tripled between 2013 and 2015. The financial crimes regulator AUSTRAC says that real estate transactions are an established money laundering method in Australia. Around AUS\$1 billion in suspicious transactions connected to property deals from Chinese investors alone were recorded in 2015/2016.

China: The research paper by Naheem concludes by reiterating the fact that China like all other countries is now operating in an international banking context, in much the same way that international organised crime is also operating at a global level. It also emphasises that real estate remains a targeted sector for criminals seeking to launder funds (Naheem, 2017).

Taiwan, China: Chen Shui-bian, the former President of Taiwan, was sentenced to 19 years in prison in 2009 after being convicted of money laundering and bribery charges. It was alleged that some of the money accepted as bribes by his family was used to purchase real estate overseas, including a $£ 1.6$ million apartment in New York (Accuity et al., 2019).

Southern Africa: According to Goredema (2004), Zimbabwe's former Minister of Finance, Chris Kuruneri, faced charges of violating foreign currency control laws by withdrawing foreign currency from a Harare bank and transferring it to South Africa. Papers filed in the case allege that he unlawfully withdrew R5.2 million (US\$800,000) from the Jewel Bank (previously known as the Commercial Bank of Zimbabwe) in March 2002. The money was passed on to a firm of attorneys in Cape Town to invest in the city's residential property market and was used to acquire a property in a Cape Town suburb. The house, which is reported to be valued at R30 million (US $\$ 4,615,384.60$ ), was registered in the name of a shell company. It also appears that some of the proceeds of grand corruption in Angola and the DRC have been invested in residential property in South Africa. More than 20 such properties in the up-market Sandton area of northern Johannesburg have been traced to serving government ministers in the DRC. 12 other properties linked to former and current military officials in Angola.

Many nations are united in the need to tackle the growing problem of money laundering through real estate. Real estate professionals, as the gatekeepers of the sector, are perfectly placed to act as de-facto regulators. The willingness of governments in key jurisdictions, combined with concerns over rising property prices and the possible link with money laundering, is creating a perfect environment for regulatory action. The sector should also expect a corresponding increase in enforcement action, regulatory checks and visits. The AML obliga- 
tions placed on real estate professionals should be similar to those that already applicable to banks and casinos. In practical terms, real estate firms and brokers, title insurance companies, real estate management companies, law firms and lenders will need to:

1) Carry out more detailed and intensive customer due diligence, including KYC checks and Politically Exposed Person (PEP) screening;

2) Screen individual transactions for suspicious activity;

3) Establish the ownership of companies involved in real estate transactions;

4) Prepare regular AML compliance reports and keep documentation for the relevant authorities;

5) Be able to demonstrate to regulators that they have robust AML screening and compliance procedures in place;

6) There is work to be done as many real estate firms are under prepared as can be seen by low levels of Compliance measures in the sector and high levels of money laundering risks.

\subsection{Conceptual Framework}

In many countries, the real estate sector is vulnerable to money laundering due to a high number of factors including; the high value of assets, price fluctuations and speculation within the market, difficulties in assessing the true value of a house, and the fact that the legal owner is not necessarily the economic owner (Unger \& Ferwerda, 2011). The Financial Action Task Force has set out international standards that the real estate agents can adopt and implement in order to protect themselves from money laundering. The standards are in line with what has been highlighted below by Friedrich and Quick (2019) in his analysis of AML in the German Non-Financial Sector (Table 1).

Table 1. Requirements for an effective AML framework.

\begin{tabular}{|c|c|}
\hline Requirement & Short Description \\
\hline Customer Due Diligence & $\begin{array}{c}\text { For some transactions, especially for cash transactions } \\
\text { USD10,000, above companies have to conduct } \\
\text { CDD (Customer Due Diligence procedures). } \\
\text { Depending on the risk, there are simplified } \\
\text { and enhanced CDDs. }\end{array}$ \\
\hline Internal Controls & $\begin{array}{l}\text { Independent of trigger-transactions, all companies have } \\
\text { to establish risk-based internal AML controls, e.g. } \\
\text { - Business-customer-related } \\
\text { - AML training for employees } \\
\text { - Employee reliability checks }\end{array}$ \\
\hline AML Officer & Designate an AML Officer \\
\hline Suspicious Transaction Reports (STRs) & $\begin{array}{l}\text { File suspicious transaction reports where there } \\
\text { is a suspicion of money laundering }\end{array}$ \\
\hline
\end{tabular}

Source: Friedrich \& Quick (2019): An analysis of AML in the German Non-Financial Sector. 


\section{Methodology}

A descriptive cross-sectional study was carried out in Lusaka District among the real estate agents based in Lusaka district. Lusaka province where Lusaka district is located in the capital city of Zambia and one of the most densely populated cities in Zambia. A mixture of qualitative and quantitative research was conducted through administering of questionnaires to a sample of the target population. A survey questionnaire that was developed was a self-designed questionnaire and assessed various issues about anti-money laundering. The questionnaire had sections that were asking respondents about general issues and a section about elements of an effective Anti-Money Laundering framework. A participatory research based on the survey questionnaires was used that seeks to bring together action and reflection, theory and practice, in participation with others, in the pursuit of practical solutions to the issues at hand. The questionnaire included closed-ended questions which were a majority and a few open-ended questions. Open-ended questions were used to solicit for additional information from respondents while close-ended ones provided answers for respondents to choose from.

Further, the population in this study consisted of all 170 registered Agents with the ZIEA as of $26^{\text {th }}$ September, 2019. A sample of 62 was drawn based on the population of 170 registered Real Estate Agents in Lusaka District. A confidence level of $95 \%$ and a margin of error of $10 \%$ were used. A combination of probability (simple random Sampling) and non-probability sampling were used to sample the participants. A questionnaire-based approach was selected for the data collection in this study. The formula used for sample size calculation was:

$$
\mathrm{n}=\frac{(\mathrm{Z})^{2} * \operatorname{StdDev}^{*}(1-\operatorname{StdDev})}{(\text { Margin of Error })^{2}}
$$

where:

$$
\begin{aligned}
& \mathrm{n}=\text { Sample size }=62 . \\
& \mathrm{Std}=\text { Standard deviation }=2.01 . \\
& \mathrm{Z}=\mathrm{Z} \text { Score at } 95 \% \text { confidence level }=1.96 . \\
& \text { Margin of Error }=+/-0.1 \% .
\end{aligned}
$$

\section{Results and Discussion}

This section gives the research results of the study. The specific determinants that were used to explain whether money laundering in the real estate sector is affected by their existence are suspicious transaction reports, AML Officer, Internal Controls, Customer Due Diligence and AML Knowledge/Training. The above-mentioned variables were analysed using regression analysis to examine the relationship between two or more variables of interest in order to examine their influence on the dependent variable (money laundering in the real estate). Further, the section discusses descriptive statistics on the entire sample of observations and cross tabulations were employed in some cases. In this Journal, 
the researcher focuses on identify factors that lead to Money Laundering in the real estate sector in Lusaka district.

Table 2 shows the attributes of the participants in the study.

\subsection{Discussion of Results from Open-Ended Questions}

The researcher formulated 4 open-ended questions in the research questionnaire which were meant to solicit for information from the research participants. One of the four formulated question which was meant to address objective one is discussed below.

In an open-ended response question, respondents were then asked to give challenges they faced in terms of complying with AML requirements in the real estate sector. The challenges given included the following: 39 real estate agents indicated that there was lack of or inadequate proper guidance, awareness and training on AML issues in the real estate sector as a result of this, there is no effective management of money laundering in the sector. Additionally, some respondents

Table 2. Sample profile.

\begin{tabular}{|c|c|c|c|}
\hline Variable & Description & Frequency & Percent \\
\hline \multirow{2}{*}{ Gender } & Male & 46 & 74.2 \\
\hline & Female & 16 & 25.8 \\
\hline \multirow{6}{*}{ Age } & 20 or under & 1 & 1.6 \\
\hline & $21-30$ & 31 & 50.0 \\
\hline & $31-40$ & 22 & 35.5 \\
\hline & $41-50$ & 6 & 9.7 \\
\hline & $51-60$ & 1 & 1.6 \\
\hline & 61 and above & 1 & 1.6 \\
\hline \multirow{4}{*}{ Education level } & Secondary and below & 8 & 12.9 \\
\hline & Diploma & 17 & 27.4 \\
\hline & First Degree & 30 & 48.4 \\
\hline & Masters & 7 & 11.3 \\
\hline \multirow{3}{*}{ Place of residence } & High density area & 17 & 27.4 \\
\hline & Medium density area & 20 & 32.3 \\
\hline & Low density area & 25 & 40.3 \\
\hline \multirow{2}{*}{ Heard of AML } & Yes & 59 & 95.2 \\
\hline & No & 3 & 4.8 \\
\hline \multirow{2}{*}{$\begin{array}{c}\text { Awareness of Customer } \\
\text { due diligence }\end{array}$} & Yes & 34 & 54.8 \\
\hline & No & 28 & 45.2 \\
\hline \multirow{3}{*}{ Importance of CDD } & Agree & 46 & 74.2 \\
\hline & Disagree & 8 & 12.9 \\
\hline & Nonresponse & 8 & 12.9 \\
\hline
\end{tabular}


indicated that there was lack or slow response from officers when cases of money laundering are reported and this leaves the real estate agents to wonder whether their reports were useful. Further, some respondents felt that asking questions regarding AML may affect their customer base as it may lead to the clients feel uncomfortable who will then go to other real estate agents. As a result, most real estate agent market players will only be interested in making a sale or profit thereby foregoing AML requirements. Other challenges advanced were the costly nature of implementing AML requirements, difficulty with some clients providing their business lines and source of revenue (CDD information) and lack of funding to the supervisory authority in order to carry out AML activities. Added to this, was the fact that due to globalization and digitalization, criminals have become more sophisticated making it very difficult for real estate agents to identify some money laundering schemes. One respondent went on to say:

"We lack financial and human resources to develop AML compliance capacity internally."

It was observed that most respondents indicated that there was lack of awareness and knowledge on AML matters in the real estate sector. The lack of awareness and knowledge on AML is a major contributor of increased money laundering levels in the sector. It means real estate agents are unable to identify money laundering schemes and thereby put up measures that are required in order to prevent criminals from laundering the money through the sector. This result agrees with the statistics that 33.3 percent of respondents said that the specific methods of money laundering known to them are few and 19.4 percent of the respondents that said that specific methods of money laundering were unknown to them.

\subsection{Regression Analysis}

This section presents the results after performing a multiple regression analysis; regression analysis is set of statistical process for estimating the relationship among the variables.

\begin{tabular}{ccccccc}
\hline & & \multicolumn{2}{c}{$\begin{array}{c}\text { Unstandardized } \\
\text { Coefficients }\end{array}$} & $\begin{array}{c}\text { Standardized } \\
\text { Coefficients }\end{array}$ & $\mathrm{t}$ & Sig. \\
\cline { 2 - 5 } & $\mathrm{B}$ & Std. Error & Beta & & \\
\hline (Constant) & 0.735 & 0.629 & & 1.169 & 0.247 \\
AML knowledge/training, & 0.598 & 0.159 & 0.464 & 3.752 & 0.000 \\
Customer Due Diligence & 0.006 & 0.005 & 0.157 & 1.229 & 0.224 \\
Internal controls & -0.035 & 0.015 & -0.580 & -2.430 & 0.018 \\
AML Officer & 0.082 & 0.091 & 1.192 & 0.907 & 0.368 \\
Suspicious transaction reports & -0.043 & 0.090 & -0.615 & -0.476 & 0.636 \\
\hline
\end{tabular}

Dependent Variable: Effective AML. 
The study conducted a multiple regression analysis and from the regression model above holding AML knowledge/training, Customer Due Diligence, Internal Controls, AML Officer and Suspicious transaction reports constant at zero effective AML will at 0.735. A unit increase in AML knowledge/training will lead 0.598 increases in effective AML; a unit increase in CDD will lead to a 0.006 increase in effective AML. A unit increase in internal controls will lead to a reduction of 0.035 in effective AML and a unit increase in AML Officers will lead to a 0.082 increase in effective AML. Finally, a unit increase in suspicious transaction reports will lead to reduction of 0.043 in effective AML. From the table above AML knowledge/training and internal controls had a significant relationship on the effective AML $(P<0.05)$ at $5 \%$ level of confidence. Customer Due Diligence, AML Officer and Suspicious transaction reports had an insignificant relationship with effective AML $(P>0.05)$ and $(P>0.1)$ at both $95 \%$ and $90 \%$ level of significance.

\subsection{ANOVA Analysis for the Overall Model}

The ANOVA analysis presents the influence of all the independent variables on the effective AML in real sector estate in Zambia. The results presented a p-value of 0.008 which was less than 0.05 . This indicated that the model was statistically significant in explaining the impact of the independent variables on the effective AML in real estate sector in Zambia. It is therefore concluded that the independent variables had significant combined effects on effective AML in the real estate sector based on FATF Standards in Zambia.

\begin{tabular}{ccccccc}
\hline \multicolumn{7}{c}{ ANOVA $^{\mathrm{a}}$} \\
\hline \multicolumn{1}{c}{ Model } & Sum of Squares & $\mathrm{df}$ & Mean Square & $\mathrm{F}$ & Sig. \\
\hline & Regression & 30.772 & 5 & 6.154 & 3.531 & $0.008^{\mathrm{b}}$ \\
1 & Residual & 97.615 & 56 & 1.743 & & \\
& Total & 128.387 & 61 & & & \\
\hline
\end{tabular}

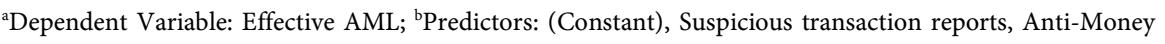
Laundering Knowledge/Training, Customer Due Diligence, Internal controls, AML Officer.

\section{Conclusions and Recommendations}

To combat money-laundering activities in the real estate sector, it is essential for the authorities and enforcement agencies to keep themselves updated with the latest methods adopted by criminals and syndicates. More importantly, any detected loopholes must be addressed as soon as possible. The research database exhibits diversified profile as the education profile of the respondents varied from secondary to master's degree. But $87.1 \%$ of them fall from diploma to master's degree category. This kind of educational maturity was expected because the study targeted real estate agent and companies based in Lusaka district. This 
maturity will help in developing the framework that addresses money laundering in the real sector based on the financial action task force standards. The study found that there is no relationship found between the highest level of education and effective AML. Therefore with regard the first objective on the factors that lead to money laundering in the real estate sector, it can be concluded that effective money laundering does not depend on the level of education one has. The study also found that most players in the real estate have less knowledge on ML and therefore there is a need for the relevant authorities such as Financial Intelligence Centre, Anti-Corruption Commission, Bank of Zambia and Zambia Institute of Estate Agents to mention a few to find means of educating and sensitizing the public on how ML is harmful to our economy.

Further, most real estate agents rarely report suspicious transactions of money laundering hence making it as one of the factors that lead money laundering in the sector. Furthermore they rarely follow the CCD and KYC procedures hence making it also a factor that leads to money laundering in the real estate sector. The other factor that leads to money in the real estate is the lack of effective and efficient internal controls for most players in the sector. Money laundering happens among common people knowingly and unknowingly through several means. If the people had sufficient knowledge and understanding on how serious a crime such as money laundering worsens the well-being of the economy they would not having being involving themselves in the activities.

For this purpose, law enforcement agencies need to devise effective strategies and mechanisms to increase cooperation at the domestic, regional, and international level to keep track of the activities that are directly or indirectly linked to money laundering. A continual and strict security on porous international borders and at airports will prevent smugglers and money launderers from moving cash from one region to another. Furthermore, by keeping a strict check on wire transfers and other methods of currency transfers, financial institutions can also play their role in tracking laundered money as well as the sources of the money, and consequently report any suspicious money transfer to the security agencies. In addition, tax authorities need to devise thorough and investigative auditing strategies in order to keep track of elites' incomes, so that no one can launder cash to avoid taxes. For this purpose, tax revenue departments should also be made independent and sufficiently powerful so that they may not be bribed or influenced politically by any powerful elite.

Most important in lessening Money laundering in the real estate is the political will. The study recommends that the government of the day should be in the forefront in the fight against money laundering. Political discipline is of great importance because leaders must lead by examples. This will install discipline on parastatals and transform the economy into a clean environment and this builds more confidence in investors. Regional cooperation to address money laundering should be enhanced.

The private sector is recommended to ensure that they maintain a culture of 
integrity, transparency and fairness in their operations as one of the ways of reducing ML activities in our nation. Companies should design well stipulated procedures which each one of them should observe in avoiding ML in their unique sectors.

The study recommends that individual solutions are very necessary in getting rid of dirty money in the real sector. This can be made possible by people acquiring knowledge of procedures, requirements and possible time of completion of important activities. Individuals should be get used of acquiring information from the right offices, right authorities and avoid intermediation that will support money laundering activities in the real estate sector and other sectors of the economy. Reporting of ML whenever observed is critical for the development of our economy and it's a responsibility of every citizen to do so.

Finally, the study recommends that the relevant authorities should empower anti-money laundering bodies with enough powers to address every piece of money laundering in the real estate sector and act accordingly. The body must be separate from politics; laws should be made in a proper and effective manner. The laws must ensure that everyone does not support the minority group that involves themselves in these activities at the expense of the general public. Organizations and institutions have suffered administrative efficiency, brain drain, social tension and even their financial stability performance at the expense of money laundering.

\section{Limitation of the Study}

The main limitation of study was the inability to include all the real estate agents and companies in Zambia due to the cost involved in reaching out to the distant localities. Secondly the researcher encountered problems of time as the research was undertaken in a short period which limited time for doing a wider research especially when carrying out the research across the selected real estate agents which facilitated the generalization of the study findings. Thirdly, the respondents were reluctant in giving information fearing that the information sought would be used to intimidate them or bring a negative image about them or their company. The researcher however handled the problem by carrying an introduction letter from the University and assured them that the information they were to give was to be treated with confidentially and it would be used purely for academic purposes.

\section{Acknowledgements}

I would like to acknowledge all the respondents that took part in the research and the entire management of the Financial Intelligence Centre that allowed me to undertake this study.

\section{Conflicts of Interest}

The authors declare no conflicts of interest regarding the publication of this paper. 


\section{References}

Accuity et al. (2019). Retrieved from:

https://accuity.com/resources/money-laundering-and-real-estate-why-the-real-estate-s ector-should-prepare-for-regulation/

Estate Agents Act, No. 21 of 2000. Lusaka: Government Printers.

FATF (2012). International Standards on Combating Money Laundering and the Financing of Terrorism \& Proliferation: The FATF Recommendations.

Friedrich, C., \& Quick, R. (2019). An Analysis of Anti-Money Laundering in the German Non-Financial Sector. Journal of Management and Governance, 23, 1099-1137. https://doi.org/10.1007/s10997-019-09453-5

Goredema, C (2004). Money Laundering in Southern Africa Incidence, Magnitude and Prospects for Its Control: Institute for Security Studies ISS Paper 92, October.

Naheem, M. A. (2017). Money Laundering and Illicit Flows from China-The Real Estate Problem. Journal of Money Laundering Control, 20, 15-26. https://doi.org/10.1108/JMLC-08-2015-0030

Prohibition and Prevention of Money Laundering Act (PPMLA) No. 14 of 2001 (As amended by PPML Act No. 44 of 2010). Lusaka: Government Printers.

Remeur, C. (2019). EPRS European Parliamentary Research Service: Members' Research Service PE 633.154-February 2019.

Unger, B., \& Ferwerda, J. (2011). Money Laundering in the Real Estate Sector: Suspicious Properties. Utrecht: Utrecht University. https://doi.org/10.4337/9781781000915

Zambia National Money Laundering and Terrorist Financing (ML/TF) Risk Assessment (NRA) (2016). 